\title{
Think Globally, Act Locally: The Strategy of Incorporating Local Wisdom in Foreign Language Teaching in Indonesia
}

\author{
Azkia Muharom Albantani ${ }^{1 *}$, Ahmad Madkur ${ }^{2}$ \\ ${ }^{1}$ Syarif Hidayatullah State Islamic University of Jakarta, Indonesia \\ ${ }^{2}$ State Islamic Institute of Metro, Lampung, Indonesia
}

Corresponding Author: Azkia Muharom Albantani, E-mail: azki@uinjkt.ac.id

\section{ARTICLE INFO \\ Article history \\ Received: November 05, 2017 \\ Accepted: January 12, 2018 \\ Published: March 01, 2018 \\ Volume: 7 Issue: 2 \\ Advance access: February 2018}

Conflicts of interest: None

Funding: None

\begin{abstract}
Indonesia is well-known for its diversity of ethnicity, language, religion and tradition. This gives birth to the emergence of local wisdom in every region in this country. Local wisdom is certainly very meaningful because it is a part of characteristic of the nation. Unfortunately, many today's young people are not familiar, even do not know, with their local wisdoms. This should be paid more attention since local wisdom is one of the self-identity of the nation. One of strategies to preserve and inherit local wisdom is by integrating it into all lessons, including foreign language, taught at school. Local wisdom needs to be in instructional activities of foreign language teaching, even though they need to learn foreign languages, they would not lose their real identity. The application of this concept is not only to equip the students with linguistic competence but also to provide them with cultural competence. This paper discusses the importance, the reason and the practical ways of integrating local wisdom in foreign language teaching for Indonesian students. It is concluded that the integration of local wisdom is very essential and it could be executed by including the local wisdom values into the materials, allocated time for discussion on local wisdom, classroom activities and the process of teaching linguistic skill.
\end{abstract}

Key words: Local Wisdom, Integration Strategy, Foreign Language Teaching

\section{INTRODUCTION}

In view of the recent numerous crises faced by mankind, an emphasis from a knowledge-based education to wisdom based education changes. The students' abilities, skills, and character buildings should be covered in instructional actions at schools. Knowledge, skill, and character are considered to best prepare the students to be greatly competitive human beings so as to answer to challenges of global and modern eras. This is a nonstop process until students graduate from the schools where they are required to take a number of subjects existing at schools.

The students' gaining knowledge, skills, and strong characters is required and compressed in the Regulations made by the Government (Taufik, 2002). In attempt to realize this intention, teachers, instructional materials, as well as schools are to be ready to come up with various innovations and strategies (Tianto, 2010). One of necessary instructional materials to pay closer attention to is teaching material. Teaching materials are made not only to equip students with knowledge, but there is something bigger than that. They are aimed at building the characters of students (Pusat Kurikulum dan Perbukuan, 2011). One of Indonesian's very meaningful and worthy assets not yet maximally employed is local wisdom.

Local wisdom possessed by Indonesia could feasibly build the nation characters as well as the identity of Indone- sia. It is ironical that local wisdom, constituting the character traits of Indonesia, erodes along the modernizing periods of time. Local wisdom is defined as the local richness that contains policies or life viewpoints. Local wisdom serves with its function as to shape human beings to be wiser in undergoing their lives. In Indonesia, local wisdom is not necessarily applicable within local context or ethnic, but cross-cultural or cross-ethnical natures as well, in hope of establishing national cultural values.

The teaching of language is necessary to involve culture in the instructional activities. This is in line with what Buttjes (1990) emphasizes that language teaching is culture teaching. Furthermore, cultural background of the learners is one of the aspects that the teacher must pay attention. Brown (1990) also maintains that cultural background is one of aspects on which language may be dependent. In this case, local wisdom existing in certain areas in Indonesia can be more maximized to have a role in teaching the language learners. Therefore, regarding with the essence of integrating local wisdom in everyday lives, particularly language teaching activities, the teachers in different places highly need to consider to include the local wisdom available in the region where they are teaching.

Local wisdom possessed by Indonesia, as stated by Anggraini and Kurniawati (2015), could possibly shape the 
nation characters as well as the identity of Indonesia. It is caustic that local wisdom, establishing the character personalities of Indonesia, corrodes along the modernizing periods of time. Local wisdom can be understood as the local richness that comprises rules or life view points. Local wisdom assists with its function as to shape human beings to be wiser in experiencing their lives. In Indonesia, local wisdom is not essentially applicable within local context or ethnic, but cross-cultural or cross-ethnical natures as well, in hope of founding national cultural values.

No one can guarantee that the inheritance of local wisdom from one to another generation could successfully run time by time. Local wisdom has been worn along the time due to globalization and modernization. It is without any doubt that local wisdom, which serves as guidance for good deeds, will be in extinction and remain as merely a history. This symptom has been appointed recently. Young generations jump to behave individualistically as they are used to modern facilities and thus no longer necessity to be in direct contact with their peers. They are also familiarized to something instantaneous as the influence of globalization and modernization that obstinately offer affluence and haste in achieving things.

One of mind-blowing local wisdoms in Indonesia is local languages. It is very hard to pricesly describe how diverse Indonesian are. According to Martí et al. As cited by Riza (2008: 93-94), there are 726 languages in the country; making it the world's second most diverse, after Papua New Guinea which has 823 local languages. To make every citizen can communicate each other as well as increase the "unity in diversity" sense among Indonesian people, Bahasa Indonesia is legalized as the national language. With this national language, all Indonesians whenever and wherever they are, they are able to talk each other. For example, Javanese people are able to easily to speak to Minang people by speaking Bahasa Indonesia language.

Despite the massive local languages, there some foreign languages learnt by Indonesian people such as English, as the most widely learnt one, Arabic, Japanese, Mandarin, Korean and others. They are taught for diverse purposes like academic and business and purposes. The teaching of foreign languages is certainly involving teaching the culture where the foreign language comes from. To illustrate, when learning English, Indonesian students will certainly learn and know culture of some English speaking countries like USA, UK, Australia and so forth. As a result, the students would be possibly influenced by the western cultures and then imitate them. At worse, the students can perceive that western culture is better than Indonesian culture. If this kind of condition continues time by time, it is not impossible that their original culture, as Indonesian, will be little by little reduced and then lost. To be one of alternatives, the foreign language teacher should creatively integrate the Indonesian local wisdom in teaching the foreign languages. By doing this so, the teachers are, "killing two birds with one stone", implementing both foreign language teaching and Indonesian students' identity protection.

\section{METHOD}

This was a library research involving a number of literatures were limited in thesis and research-based articles in journals. We collected a number of studies in relation with this topic to compare the distinction and similarities among them. When we searched the sources, we consistently used some specific terms such as foreign language teaching, local wisdom in teaching, and values integration. This was to drive us to not go beyond the discussed topics. The articles collected were from diverse perspectives to gain a deep understanding on the importance of local wisdom and how to practically integrate it in the teaching of foreign language. To more deeply understand and then find the sources containing information about the issue of this article, we attempted to relate a research result with the other research results.

\section{DISCUSSION}

\section{Local Wisdom: What and Why?}

Talking about local wisdom, we usually refer to indigenous people. Cambridge Advanced Learner's Dictionary describes indigenous as naturally presenting in a place or country rather than incoming from another place. So it belongs to particular indigenous people and their knowledge. Indigenous knowledge is local knowledge unique to a given culture or society. It is the systematic body of knowledge acquired by local people through the accumulation of experiences, informal experiments, and an intimate understanding of the environment in a given culture. Indigenous knowledge evolved from years of experience and trial-and-error problem solving by people working in their environments. Source of knowledge management relating to their production derive from their local knowledge and traditions originated by their ancestors. This indigenous knowledge has been modified through accumulated practical experiences and passed on from one generation to the next. Meanwhile, local wisdom, according to Moendardjito ib Kultsum (2014), consists of two words: wisdom and local. In dictionary of English-Indonesia, whereas local (lokal) means local (setempat); wisdom (kearifan) means wisdom (kebijaksanaan) (John M Echols and Hassan Syadily). In general, it is stated in Saputra (2013) that the local wisdom can be understood as local ideas that are thoughtful, full of wisdom, good value, embedded, and followed by the people (Sartini, 2009).

Other definition by Mungmachon (2012: 176) explained that local wisdom is basic knowledge originated from balanced life with nature. It is actualized in relation with culture in the community which is gathered and passed on. The form of this wisdom can be both abstract and concrete, but the essential features are that it arises from experiences or truth increased from life. The wisdom from real experiences assimilates the body, the spirit and the environment. It highlights respect for elders and their life experiences. Moreover, in local wisdom, morals are consider more valueable than material things.

Besides, local wisdom, as elaborated by Meliono (2011) may also be symbols and symbolic interactions that come from the interaction between the people and it becomes so 
vital to signify the responses adjacent to the elements of the local wisdom. Symbols become essential when people learn from the experience, because one tries deeper to solve the meaning of the symbols. Through symbols, people will think and recognize more the significance in a wise way. Cultural symbols that came from local myths, crafts, and rituals may be learned and presented as a form of the local wisdom that reflects the dynamic nature of its culture, enduring, creative, and innovative. In the disciplines of anthropology, the term local wisdom has known as local genius. The features of local wisdom are:

1) Able to withstand foreign cultures

2) Having the ability to accommodate the elements of foreign cultures

3) Having the ability to integrate elements of foreign culture into the native culture

4) Having the ability to control

5) Being able to give direction to the development of culture.

Why does the local wisdom need to be involved in foreign language teaching? Referring to this question, Meliono (2011: 1) stressed that education is one of the suitable media that is precise and effective to generate a young generation who is able to create an inquiring mind, wise, open-minded, and constructive attitude. The general education which contains the complimentary subsystems, spread to the regions in the Indonesian archipelago, and to the different levels of state and private educational institutions. It is, therefore, the state of education has to hold a clear goal in order to achieve an accurate and ideal objective. In a cultural paradigm, education should embrace pluralism and multiculturalism. It has become a crucial necessity demanding planning. In addition, with the incorporation values of local wisdom in teaching, it is projected that students will have an understanding of their own local wisdom, raising a sense of love toward their own culture.

\section{Indonesian Local Wisdom and Foreign Culture}

Indonesia is a pluralistic nation with the variety of language and culture. It has several hundred ethnic and sub-ethnic groups (Thung Ju Lan, 2011). As a result, numerous and diverse local wisdoms appear and exist in each region. However, some anthropologists have already formulated the Indonesian local wisdoms in general way. Among others are theological values, politeness, friendliness, tolerance, politeness, tact, secondary function, dare budge, and mutual aid (commonly known in Indonesian language as gotong royong). This general values of local wisdoms can be both explicitly and implicitly implanted into the process of teaching and learning aspects: materials, instruments, methods and so forth.

Furthermore, Indonesian also has a tradition by which they keep in touch not only with human but also with the nature surrounding them. It needs to be noticed that Indonesian nation has a strong culture and a kind of agreed unwritten rules to show respect to the nature. This long-preserved tradition is nowadays actualized in some governmental regulations. Besides, in local wisdom formulation, there should be also nationalism aspects as a unifying tool for the variety of ethnics existing in Indonesia. To conclude, the local wisdoms consists of the relationship between man and God, social values and the relationship between human and nature.

The same thing is done in various foreign countries, such as the West countries, through the efforts of more modest, given the foreign nation is not like Indonesia in cultural diversity issues. To the West, the local wisdom at their disposal, among which are: the value of freedom, ownership, democracy, responsibility, independence, achievement, humanity, brotherhood, hard-working, self-actualization, self-respect, and the best performance (Baginda, 2012).

As for the Arabic countries, there are some local wisdoms at their disposal compared with Western nations, the Arabs are more likely to values which almost has in common with the people of Indonesia, among them: the value of divinity, welcoming, tolerant, polite, poetic attitude, and complimenting (Azzuhri, 2016). Since the Arabic culture is strongly influenced by the Islamic teachings, their local wisdom is mostly the reflection of the Islamic values. This characteristics of Arabic tradition are more or less similar to Indonesia since it is the world' most populous Moslem country.

These values are disseminated through a variety of occasions, including a state occasion. This wisdom is also introduced to Indonesian learners through the books of foreign language teaching materials. This is again the case for the introduction of the drafters to realize the importance of culture in foreign language learning process. Once known indigenous people of Indonesia and foreign nations then appeared two hypotheses, whether these two cultures will collide with each other, or even complementary.

Government Regulation No. 19 Year 2005 on National Education Standards Article 17 paragraph 1 indicates that the level curriculum for elementary through high school education, or other equivalent form is developed in accordance with the educational units, regional potential, social, cultural, and learners. Thus, the whole process of learning in an educational institution must be very attentive to charge local knowledge, including in foreign language learning. In addition, the learning based on local wisdom has the same goal with the national education goals, as stated in Law No. 20 of 2003 on National Education System Article 3, that the national education serves to develop the ability and shape the character and civilization of dignified nation in order enrich the life of a nation. National education aims at developing students' potentials in order to become a man of faith and fear of God Almighty, noble, healthy, knowledgeable, skilled, creative, independent, and become citizens of a democratic and accountable.

At the time being, on the Curriculum 2013, the affective emphasis and thematic integrative learning would provide support character education in foreign language learning. Learning that is both integrated and contextual practices can contribute in capturing indigenous issues within the culture. Foreign language learning is highly relevant based on contextual learning to apply. The most important thing in an effort to dig the nation's character is the excavation and reinforcement of national cultural treasure. It is thus pursued in order to strengthen the national character of the young 
generation becomes a necessity (Sultoni, et.al, 2015). Meaning to say, in the effort of struggling to reduce the problem of demoralization of young generation, local wisdom-based teaching is considered urgent to implement. Therefore, the local wisdom-based learning will contribute in giving birth to generations who are competent and dignified, reflecting the cultural values, taking a part in shaping the character of the nation, contributing to the creation of national identity, and participating in preserving the culture of the nation.

\section{Cross Cultural Understanding}

Understanding the diversity of cultures and civilizations that exist in the world today is not to judge the local wisdom which is better and which is worse, but to know each other and in turn mutual respect. Indonesian people who are learning foreign languages does not make the foreign culture as the target culture for them, but rather to make the foreign culture as one of the disciplines which must be understood to master foreign languages in a comprehensive manner. Therefore, the planting of local wisdom in learning foreign languages is not an impossible one, even it is possible to do. Meaning to say, local wisdom values will not interrupt the main goal of foreign language teaching.

According to Knutson (2006), the standards and objectives for language learning have throughout this time stayed relatively unchanged, the overall goal of language teaching has, in effect, extended, and 'doing it all'- evolving language ability in four skills and familiarizing students to a comprehensive array of cultural material, while keeping LI use in classroom interaction to a minimum-has become the undeclared commanding. Therefore, even though this is not clearly stated, the teachers should pay attention to this issue of culture content in the materials.

Local wisdom functioning as cultural identity is one of the factors causing cross cultural interaction in foreign language teaching; it can be harmoniously implemented academically and not dominates each other. Local wisdom as identity of a certain community is not easily replaced by other local wisdom in the other community. In addition, local wisdom as self-identity is also able to accommodate the elements of foreign culture that is considered relevant and then making it a part of their own culture. All of these elements become a kind of foundation for their own culture to dynamically interact with the other cultures.

Actually, it is not exaggerate to say that there is always similarity among local wisdoms. When analyzed, for example, the western culture has some similarities with Indonesian local cultures. The similarities found are among others:

1) Indonesia and the West consider the values that must be used as a system for the society's structural and social management must be based on democratic and responsible values. Both of the cultures share their same perception in this field.

2) The West values consider the independence, achievements, brotherhood, and work ethos as the social development values. Indonesia sees this case similarly.

3) To build good relationship with a variety of parties, including with foreign cultures, Indonesian and western local wisdom emphasize universal human values. This leads to the attitudes of the nations which tends to be netral in various conflicts occurring in the world (Baginda, 2012).

In addition, Arabic local wisdom has many similarities with Indonesian local wisdom. Some things that can be analyzed are among others:

1) Indonesia is a country with a majority of Muslims, a religion born in the territory of the Arab nation. It is undoubtedly said that Indonesia was dubbed the oriental culture that upholds the values of divinity and hospitality.

2) Arabic wisdoms view the values of brotherhood as the society's welfare builder. The same thing was also deemed important by the nation of Indonesia.

3) Not much different from Western nations, to build relationships with various parties, including the foreign culture, Indonesian local wisdom and the Arabic local wisdoms emphasizes universal human values (Azzuhri, 2016).

Many similarities elements of local wisdom in Indonesia and foreign culture into a marker will be harmonious interaction between the two cultures. It is at once dismissed fears of cultural conflicts within foreign language learners concretely that will interact with the culture of foreign nations and their wisdom in the learning process. However, there are things that must be examined in more depth related to "difference" between the moral values of the Indonesian nation with the West, which is the value of freedom, ownership, and self-actualization. Freedom in Indonesia tend to be placed in the second position after the ethics, politeness and friendliness. In the social context of Indonesian people will not argue freely when he looked at his opinions could potentially harm the other party. Therefore, Indonesian people tend to hold on secondary functions, subject and attitude ready to succumb (Firdaus, 2013).

In the political context, freedom of expression is fully governed by laws, such freedom is rooted in the life of the nation for a long time. The same rule we find the value of 'self-actualization'. 'Ownership of private' does not become the priority in indigenous Indonesian and Arabic. Our society adhering to the values of mutual cooperation and togetherness. This indicates openness and privacy of the small space in the local wisdom Indonesia. It also tends to be found in Arab culture. Indonesian and Arabic are also used to make small talk and routines between community members. Various things are hard to find in the West in people who have not been too familiar, because it violates the boundaries of personal privacy (Pure and Wati, 2013).

One thing that is different to the Indonesian nation is not showed element of divinity in the local wisdom of the West. The issue of religion in Western society is seen as a private matter. That is why religion is not the basis for any government regulation. Additionally, inquire religion unknown person close to very likely be considered a violation for the privacy of the person. In addition, some Western countries even ban the wearing of religious symbols in educational institutions, both religious symbols in the form of worship or 
not. This is clearly different from Indonesia, where religious symbols are shown not only free in public spaces, but also to be an attribute in many state occasions. Almost in every event, there is a prayer led by religious leaders, and their religious expressions in official speeches. Thus, on the side that the Indonesian people have more in common with the Arabs whom religion is not a privacy, but rather an independent identity displayed (Ristiani, 2014).

An understanding of these differences are supposed to be delivered as well as learning foreign languages, because of the implications of lack of proper understanding of the differences can potentially be a problem in the future, such as foreign language learners to interact with native speakers (Jeniarto, 2013). Here is a Table 1 that explains the similarities and differences in the charges of local wisdom in general contained in the Indonesian nation, the West and the Arab nation. The variety of things to note in learning foreign languages (English/Arabic) for the Indonesian students.

\section{Local Wisdom Content in Foreign Language Teaching}

It has been long known that there is a kind of margin of education when English language teaching is implemented. Some teachers still have a perception that their responsibility is only for teaching the language. Not many teachers perceive of paying attention to general educational development of the student. Littlejohn as cited by Fitriani (2012: 283) remind us, English teachers, about whether realize it or not, the students will surely learn more in their language classes than just language. Meaning to say, it is clear now that culture and teaching language are inseparable and interconnected harmoniously. As a consequence, the teachers should not deny the importance of instilling local wisdom in foreign language teaching. Douglas H. Brown as cited by Richards and Renandya (2002: 12) declares that, "whenever you teach a language, you teach also a complex system of cultural customs, values, and ways of thinking, feeling and acting". Hence, it is considered a crucial matter that all teachers and stakeholders involved in the practice of teaching foreign language must have awareness and sensitivity regarding with the issues of diversity between foreign language and the local language as well as the national language, in this case, Bahasa Indonesia.

Foreign language teachers are supposed to strive to develop inner wisdom based noble values contained in the local wisdom of the Indonesian nation. Character development based on local wisdom that was rife implemented through a variety of other disciplines, it is fitting also confirmed in the foreign language learning process. It can support the formation of a learning soft skills are very large, so that each graduate will be individuals who are not only skilled foreign language, but also able to use them properly. In addition, they will have a broad insight into a foreign culture, and have the wisdom and scientific personalities. The delivery charge of local wisdom in learning foreign languages can be done in an integrated manner in the delivery of learning materials, and more specifically addressed in the study of foreign cultures that exist in any foreign language teaching materials. Here are some of the opportunities that could be exploited by all activists of foreign language learning in various levels of education (Nadlir, 2014). Furthermore, Septy (2016: 83) highlights that the local wisdom content can be one of the components of language materials. Consequently, the teachers need to manage the lesson materials consisting such cultural values-local wisdoms in foreign language, like English, teaching.

Involving local wisdom in foreign language teaching can stimulate and attract the students to study. A study conducted by Thipwimol Wangkaewhiran (2012), revealed that the students were pleased in a high level of teaching and learning from the local wisdom learning unit incorporated to ASEAN which was designed by the model especially in the items of the interesting instructional activities, and the students enjoyed their participation in learning activities. This was because the teacher had been prepared a valuable lessons for them, not only underlining on the curriculum standard but also concentrating on the local wisdom. This local wisdom features made the students feel familiar with the materials given by the teachers.

\section{How to Incorporate the Local Wisdom in Foreign Language Teaching?}

It would be useless if the importance of local wisdom in supporting educational process stops in only being a discourse. There are some applicable strategies, among other strategies, that could be executed by the teachers and also policy makers in educational field.

\section{Through the features of the given materials}

Language materials are those resources that can be used to facilitate language learning such as course books, videos,

Table 1. Local wisdoms in Indonesia, the West, and Arab, adopted from Saputra (2013: 619)

\begin{tabular}{llll}
\hline System & Indonesian & Western & Arabic \\
\hline $\begin{array}{l}\text { Technology and } \\
\text { production tool }\end{array}$ & Machine & Machine & Machine \\
Knowledge & Less reading & Love Reading & Less reading \\
Occupation & The minority of scientists & The majority of scientists & The minority of scientists \\
Religion & The majority of Muslim & The minority of Muslim & The majority of Muslim \\
Social lives & Solidarity, mutual aid & Stressing on privacy & Islamic brotherhood \\
Language & Indonesian Language & The majority of English Language & Arabic Language with diverse dialects \\
Art & Local and modern & Modern & Islamic art and modern \\
\hline
\end{tabular}


graded readers, flash cards, games and websites (Tomlinson, 2012). Materials, according to Maroko (2013), can inform the learner about the target language; guide the learner in practicing the language (instructional function); provide the learner with experience of the language in use (experiential function), encourage the learner to use the language (eliciting function); and help the learner to make discoveries about the language (exploratory function).

In the foreign language course book, there must be information that can be discussed in the classroom to build foreign culture understanding in the learners' mind. Each of information presented must be matched with the discussion theme and it is displayed in eye-catching way. Therefore, when the students want to find the specific lesson, it will be easy for them to find (Baginda, 2012).

The other information that must be included in the material is, among others, about the pluralism of people, currency, regions, and also the contemporary issues occurring globally. In order to make the learners understand this knowledge, the teacher can conduct contrastive study on numerous incidents and traditions in Indonesia while teaching the local wisdoms in Indonesia without describing foreign culture and Indonesian cultures in negative way. Thus, local wisdoms values can be delivered in the context of the harmony of two culture, not crashing the Indonesian culture and foreign culture.

One of the illustrations is, to make an example, when explaining about the kinds of professions and job carriers. When talking about unemployment which indeed happens in both Indonesia and western countries, it is agreed that grumbling and blaming the condition of country will not be a problem solution. Because it is basically agreed that when someone cannot get a job, it is not the country's fault but mostly he/her skill and achievement. Something that the students must be directed is that they should get the assignment to answer the possible job or occupation that can be taken when someone is pursuing a degree in university. To illustrate, the teacher asks to the students, what kind of occupation that can be taken by a student of foreign language department after he graduates with excellent score? Through this strategy, the learners are motivated to always study hard, believing that knowledge will definitely give benefit and good impact to the future.

\section{Involved in classroom activities}

Foreign language learning is rich with opportunities to strengthen the identity of learners in accordance with Indonesian local wisdom. This is possible because the themes generally revolve problems learning everyday problems, such as work, eat and drink, travel and so on. As we understand it, local knowledge is also a life wisdom that governs human relationship with the problems of everyday life. This slice will open up vast opportunities for foreign language teaching based on local wisdom.

One of the activities that can be done is to give the problem to be solved together independently before being addressed through discussions. This activity will strengthen the learner's ability and readiness to actively contribute to the mutual interest, receive and submit ideas through commu- nication good ethics, and hone the ability to work in teams. In turn, this activity is expected to eliminate the potential birth of individualistic attitude in the process of socialization (Baginda, 2012). It also positively affects the students' foreign language competence since the better the relationship among the students, the better they could share and exchange their knowledge.

\section{Allocated time for discussing local wisdom values}

Within the hours of foreign language learning which is sometimes lasted a long time, teachers can innovate by creating activities capable of reviving the motivation and interest of the students, but still related to foreign languages. Among the usual things are short songs to teach foreign languages. This activity proved to revive the attention of learners sometimes to the point of saturation in absorbing the learning classes long duration. Additionally, song also a rehearsal for the pronunciation of the phonemes of foreign languages are sometimes difficult for Indonesian learners' vocal organs. This kind of time can also be filled with foreign cultural contrastive study with Indonesia (Baginda, 2012). The local wisdom can also be introduced in popular fairytales which commonly contain moral values good to be learned by the students.

For foreign language learners who have generally never been in the country to foreign languages, delivering information about the culture foreign and attitudes of those foreigners who are contrasted with the same thing in Indonesia will be seen attractive and able to revive motivation and interest in the fading due to learning in long term. It would be more interesting if teachers use audio-visual media. "Refreshing" of this kind will be able to restore the readiness of learners receive further material. In addition, the learner cultural insights will be global and local knowledge that is delivered will equip students with the personality of the character (Albantani and Madkur, 2016). This is in line with the goal of curriculum 2013 that strongly emphasizes the character building for the students.

\section{Local wisdom-based materials}

The understanding on local wisdom can also be delivered through material design development for foreign language teaching. The material must be arranged to reach the communicative purpose of target language. In doing so, the materials can be displayed and delivered in the thematic form. The themes chosen must reflect local knowledge as one of the discussions. In addition, materials are arranged in the teaching materials should include a discussion of the target language culture, local culture, and international culture. Thus, learners will master a foreign language in a comprehensive manner, not only able to communicate with a foreign language as well, but also understand the culture of the speakers of the language (Baginda, 2012).

There are advantages and disadvantages of teaching materials prepared by the speakers of the target language speaking learner. If the teaching materials prepared by native speakers, then that will be the dominant culture is the culture 
Table 2. An example of a part of material integrating local wisdom within it. This is taken from the book of Bahasa Inggris: When English Rings a Bell SMP/MTS Kelas VIII published by Ministry of Education and Culture of Indonesia

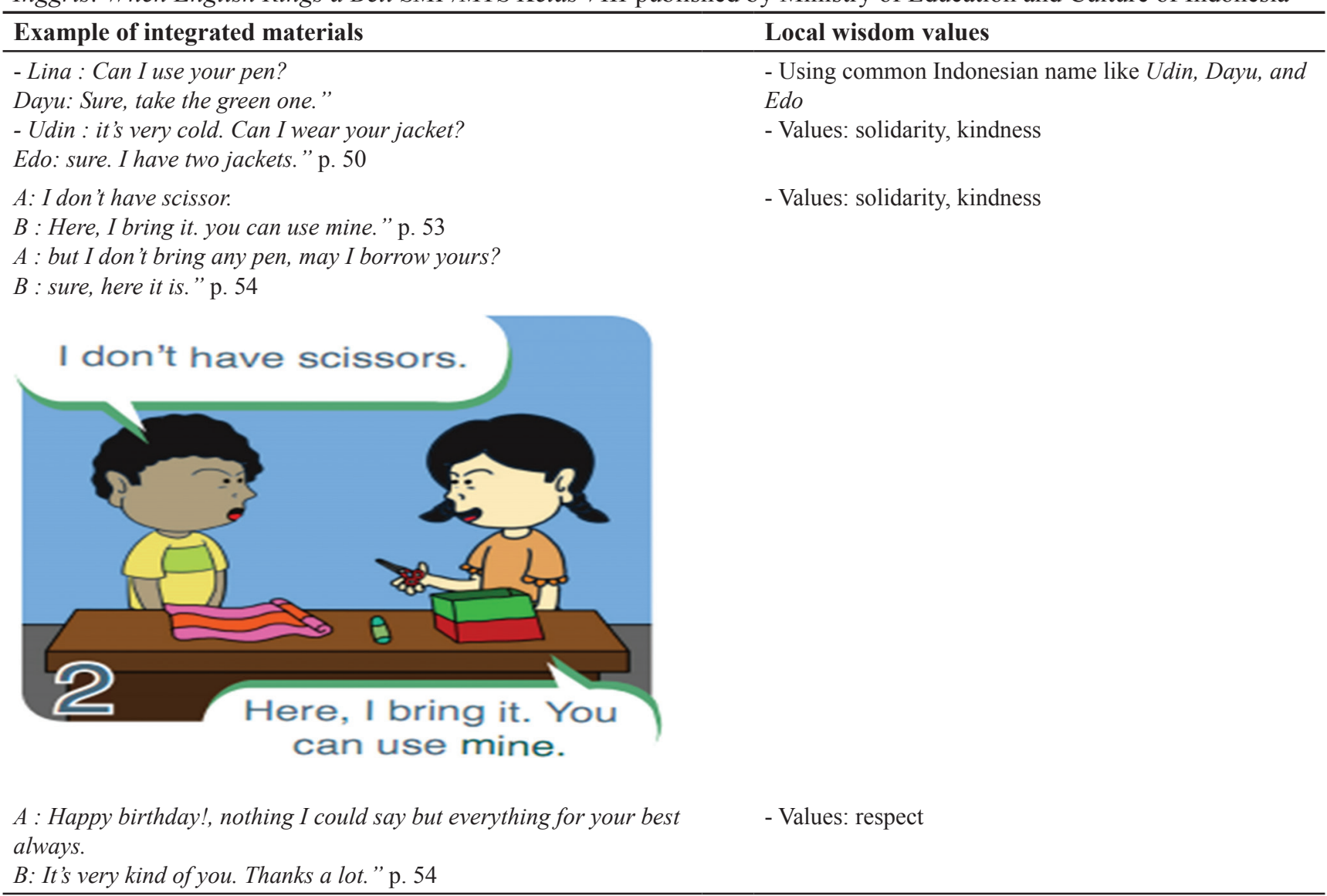

of the target language. If the teaching materials prepared by non-native speakers, then that will be the dominant culture is the local culture. However, it can be anticipated with the preparation of the competence for foreign constituent materials. Debriefing culture is necessary so that the compilers of foreign language teaching materials derived from native speakers in a draw learners are able to present charges the target language culture, local culture, and international culture. The briefing can be done by providing the opportunity for the constituent materials to settle down some time in the country to which the target language so that he would understand the cultures that occurred there (Saputro, et.al, 2014).

\section{CONCLUSION}

The integration of local wisdom values in the instructional activities is also in relation with the instilling of nationalism spirit into the students' character. By integrating the local wisdom values in the teaching of foreign language, it is expected that the students will possess good understanding about their worn local wisdom; as a result, it grows the respect and love toward their culture. In addition, the students also understand and then, hopefully, can filter the other cultures spreading outside of Indonesia.

When integrating local wisdom value in the teaching of foreign language, the teachers should match and adjust it to their level of the students' growth, suiting with the delivered materials, and the teaching method applied in the instruction. The local wisdoms values-based teaching educates the students to always be close and able to cope with the real situation they are involved in their everyday lives. In other words, it might be said that this type of teaching, even though including foreign culture, invites all the elements of education to not stay away or leave the values which are preserved well in the society, especially the community where they come from.

\section{REFERENCES}

Albantani, A.M., Madkur, A. (2016). Integrating Character Education Values in Language Teaching: Why and How?. A paper presented in The $4^{\text {th }}$ ELITE International Conference 2016, Jakarta. 400-414.

Azzuhri, M. (2016). Bahasa dan Kearifan Lokal: Harmonisasi Sosial Masyarakat Arab - Jawa di Kampung Arab. Arabi: Journal of Arabic Studies, 1 (2), 90-101.

Baginda, P. (2012). Muatan Kearifan Lokal dalam Pembelajaran Bahasa Jerman. Allemania, 1 (2), 130-141.

Buttjes, D. (1990). Teaching Foreign Language and Culture: Social Impact and Political Significance. Language Teaching Journal, 2, 53-57

Firdaus, Q. (2013). Frail Local Wisdom, Robust Local Thoughts: Mapping the Problems. Jurnal Ultima Humaniora, 1 (2), 110-123. 
Fitriani, I. (2012). Instilling the Local Wisdom in English Language Teaching through Indonesian Traditional Game. National Seminar Proceeding, 282-289.

Jeniarto, J. (2013). Diskursus Local Wisdom: Sebuah Peninjauan Persoalan-persoalan. Jurnal Ultima Humaniora, 1 (2), 124-136.

Kaltsum, U., H. (2014). Integrating Local Wisdom in the English for Young Learners. A paper presented in The $3^{\text {rd }}$ UAD TEFL International Conference 2014, Yogyakarta. 475-482.

Kementrian Pendidikan dan Kebudayaan. (2014). Bahasa Inggris: When English Rings a Bell SMP/MTS Kelas VIII. Jakarta: Kementerian Pendidikan dan Kebudayaan."

Knutson, M., Elizabeth. (2006). Cross-Cultural Awareness for Second/Foreign Language Learners. The Canadian Modern Language Reviewfli Revue canadienne des langues vivantes, 62 (4), 591-610.

Kusnia, T and Anggraini, P. (2015). The insertion of local wisdom into instructional materials of Bahasa Indonesia for $10^{\text {th }}$ grade students in senior high school. Journal of Education and Practice, 6 (33), 89-92.

Lan, Thung Ju. (2011). Heterogeneity, politics of ethnicity, and multiculturalism: What is a viable framework for Indonesia? Wacana, 13 (2), 279-292.

Maroko, M., G. (2013). Development of language materials for national development: A language management perspective. International Journal of Education and Research, 1 (7), 1-14.

Meliono, Irmayanti. (2011). Understanding the Nusantara Thought and Local Wisdom as an Aspect of the Indonesian Education. Tawarikh: International Journal for Historical Studies, 2 (2), 221-234.

Mungmachon, R. (2012). Knowledge and Local Wisdom: Community Treasure. International Journal of Humanities and Social Science, 2 (13).

Murni, D., Wati, R. (2013). Pembelajaran Bahasa Inggris Berbasis Kearifan Lokal. A Research Report. Tanjungpinang: Universitas Maritim Raja Ali Haji.
Nadlir. (2014). Urgensi Pembelajaran Berbasis Kearifan Lokal. Jurnal Pendidikan Agama Islam, 2 (2), 300-330.

Richards, Jack, C., and Renandya, Willy. (2002). Methodology in Language Teaching: An Anthology of Current Practice. Cambridge: Cambridge University Press.

Ristiani, I. (2014). Pemilihan Model Pembelajaran Bahasa dan Sastra Indonesia dalam Pengembangan Karakter Berbasis Kearifan Budaya Lokal. National Seminar Proceeding. 1-11.

Riza, Hammam. (2008). Resources Report on Languages of Indonesia. A report presented in The Workshop on Asian Language Resources.

Saputra, G.A.S. (2013). Enhancing Local Wisdom through Local Content of Elementary School in Java, Indonesia. Proceeding of the Global Summit on Education (e-ISBN 978-967-11768-0-10), 614-620

Saputro, E., Widodo, M., Rusminto, N.E. (2014). Pengembangan Bahan Ajar Menulis Berbasis Nilai-Nilai Kearifan Lokal. Jurnal J-Simbol (Bahasa, Sastra, dan Pembelajarannya), 1-15.

Septy, Prima, Adzanil. (2016). Managing local wisdom in english teaching materials. A paper presented in Proceedings of the Fourth International Seminar on English Language and Teaching (ISELT-4), 2016.

Sultoni, A., Hilmi, H.S. (2015). Pembelajaran Sastra Berbasis Kearifan Lokal Sebagai Upaya Optimalisasi Pendidikan Karakter Kebangsaan Menuju Masyarakat Ekonomi ASEAN (MEA). National Seminar Proceeding. 229-236.

Tomlinson, B. (2012). Materials development for language learning and teaching. Language Teaching, 45 (2), 143-179.

Wangkaewhiran, T. (2012). Development of Local Wisdom Learning Management Model of ASEAN Focus School: A Case Study in Thailand. A paper presented in The Asian Conference on Education 2012. 